\title{
KMETIJSTVO V MESTNI OBČINI LJUBLJANA
}

\section{Barbara Lampič: Kmetijstvo v Mestni občini Ljubljana: relikt ali razvojni potencial. Zbirka GeograFF 2. Znanstvena založba Filozofske fakultete in Oddelek za geografijo, 123 str. Ljubljana 2008.}

V strokovnih razpravah zadnjih petih let dobivajo čedalje pomembnejše mesto alternativne prehranjevalne verige (tudi lokalna oskrba s hrano). Le-te zaradi različnih razlogov (krajše transportne poti, manjše obremenjevanje okolja, večja prilagodljivost lokalnim/regionalnim prehrambenim navadam, krepitev lokalnih/regionalnih gospodarstev, večje zaupanje kupcev v kakovost izdelkov itd.) izkazujejo očitne prednosti, predvsem z okoljskega in teritorialno vezanega gospodarskega in socialnega vidika, pred prevladujočimi in uniformiranimi silami globalizirane oskrbe $\mathrm{s}$ hrano. Tovrstna izhodišča $\mathrm{v}$ povsem novo luč postavljajo sobivanje mest in njihovega zaledja (podeželja), ko medsebojno sožitje postaja vse večja želja in zahteva sodobnega sveta.

Avtorica drugega zvezka v zbirki GeograFF poskuša s kvantitativnimi in kvalitativnimi kazalniki trajnostnega razvoja kmetij ugotoviti, ali je kmetijstvo v Mestni občini Ljubljana (MOL) preostanek preteklosti ali pa ga lahko vrednotimo kot razvojni potencial. Delo je smiselno razdeljeno v pet poglavij, pri čemer se prva štiri (Kmetijstvo v Ljubljani, Stanje in težnje v razvoju kmetijstva, Navzkrižja med naravnimi viri in kmetijsko rabo, Razvojni potenciali in perspektivnost kmetij) z različnih vidikov osredotočajo na analizo, zadnje (Prihodnja umestitev kmetijstva v razvoju Mestne občine Ljubljana) pa je sintezno-perspektivne narave. Osrednje vprašanje avtoričinega razmišljanja je, ali mesto in njegov razvoj res izključujeta kmetijstvo kot enakovredno in v razvoju potrebno prostorsko dejavnost?

Obsežna raziskava, izvedena v okviru projekta, financiranega s strani MOL (Analiza in funkcijsko vrednotenje kmetijstva z vidika vplivov na naravne vire na območju celotne MOL), je predstavljala temeljni okvir obsežnemu terenskemu delu. V letu 2000 je Popis kmetijskih gospodarstev na preučevanem območju evidentiral 924 kmetij; po podatkih strokovnih služb naj bi bilo danes v MOL približno 600 aktivnih kmetij. Raziskava jih je vključila skoraj tretjino (189 kmetij z 2285 ha kmetijskih zemljišč v uporabi), pri čemer avtorica vestno sledi trem temeljnim geografskim enotam.

Razvojni potencial kmetijstva je avtorica ocenjevala skozi prizmo naravnih virov, njihove omejenosti in občutljivosti (na primer prsti, vode). V delu je izvedena podrobna analiza agrarne strukture, pri čemer avtorica stanje v MOL dosledno primerja s slovenskim in pri tem jasno nakaže podobnosti in razlike. Pri obravnavi posameznih vidikov agrarne strukture avtorica pohvalno sledi pojasnjevanju heterogenosti v okviru navedenih geografskih enot.

Kmetijstvo v MOL je v primerjavi s slovenskim nadpovprečno specializirano, višja je tudi raven intenzifikacije (zlasti na ravninskem in barjanskem območju). V zadnjih letih se je nekoliko zmanjšala energetska intenzivnost v kmetijstvu, a je struktura energetskih vnosov (električna energija, tekoča goriva, mineralna in organska gnojila, sredstva za zaščito rastlin) 
ostala nespremenjena. Samo $12 \%$ anketiranih kmetij ima nižjo energetsko intenzivnost od okoljsko sprejemljive (15 J/ha). V primerjavi z ostalo Slovenijo je tudi izobrazbena sestava predvidenih naslednikov boljša, solidna je tudi demografska moč kmetijskih gospodarstev (analizirana je bila demografska vitalnost gospodinjstev). Očitno večji od slovenskega povprečja je tudi delež kmetij, ki nastopajo na trgu (80 \%); tržnost najbolj zaznamuje kmetije z rastlinsko pridelavo. Prevladujoča je usmeritev v govedorejo ( $42 \%$ kmetij), upada delež kmetij brez izrazite usmeritve ( $35 \%$ ), nadpovprečen je delež specializiranih kmetij (pridelava sadja, zelenjave, konjereja itd.). Pomembno je tudi dejstvo, da zaradi velikega interesa za zemljo zlasti med kmeti na ravnini (in tudi drugimi uporabniki prostora!) zemljišč primanjkuje. Kljub drobnim medregionalnim razlikam pa lahko za MOL zatrdimo, da imajo anketirane kmetije najetih skoraj 40 \% kmetijskih zemljišč v uporabi (ali 955 ha).

Pri prepoznavanju odločilnega dejavnika glede perspektivnosti preučevanih kmetij je avtorica preučila tako zemljiško-posestne razmere (povprečna kmetija v MOL poseduje 6,4 ha kmetijskih zemljišč v uporabi), energetsko obremenjevanje, kot tudi socio-ekonomski status, demografski potencial itn., in zaključuje, da bo tržna naravnanost odločilni dejavnik pri ohranjanju kmetovanja v MOL. 42 \% anketiranih lastnikov kmetij namerava ohraniti kmetijo v obstoječem stanju, četrtina jih namerava ali povečati obdelovalne površine ali vlagati v dopolnilne dejavnosti, specializacijo, posodobitve itn. Barjanski kmetje največjo oviro razvoju kmetijstva vidijo v nenadzorovani pozidavi in vzpostavitvi strožjega sistema upravljanja v okviru zavarovanega območja. Kmetje v hribovitih predelih kot največjo nevarnost bodočemu razvoju kmetijstva navajajo ogozdovanje, ravninski kmetje pa širitev stanovanjskih sosesk in gospodarskih con.

Knjiga je tudi oblikovno všečen izdelek; odlikuje jo jasno zasnovan 'spremljevalni instrumentarij’: pregledno kazalo vsebin, 41 preglednic in 52 slik (od tega kar 16 kart, kjer so s pomočjo koordinat vrisane anketirane kmetije) ter 114 ključnih gesel v stvarnem kazalu. Za naročnika je izjemno uporabno, da lahko s pomočjo kartografskih prikazov (individualno) spremlja analize merljivih odnosov kmetij do okolja in razvojne percepcije kmetov. Logični trikotnik, ki ga tvorijo proizvajalci, trgovci in kupci, je razumljivo samo nakazan, tako da ne moremo odgovoriti na vprašanje, kolikšen delež hrane, ki jo Ljubljančani pojedo, dejansko izvira iz MOL. V določenih elementih je raziskava potrdila obstoj von Thünenovih kmetijskih pasov v bližini mestnega naselja, vendar je avtorica jasno pojasnila vzroke za odstopanja (vodovarstveno območje, pomanjkanje zemlje, drobna razparceliranost ipd.). Pozitivno je tudi dejstvo, da avtorica nakazuje na metodološke in terminološke dileme in opozarja na neodgovorjena vprašanja, ki bodo zahtevala podrobnejše raziskave.

Delo je vsebinsko bogato, trditve so podkrepljene z grafikoni in kartografskimi prikazi. Bralec mogoče pogreša preprosto sintezno preglednico temeljnih značilnosti vseh pridelovalnih/geografskih enot. Avtorica je sicer predstavila glavne probleme po geografskih enotah, smiseln je tudi sintezni pregled indikatorjev vseh treh razsežnosti sonaravnega razvoja. Pričujoče delo ima veliko uporabno vrednost za naročnika raziskave, strokovne službe, posamezne kmete, v strokovno pomoč bo tudi pri študiju geografije in sorodnih ved, ki se ukvarjajo s sodobnim vrednotenjem večfunkcijske vloge kmetijstva v ali na obrobju mest. 